\title{
KLASIFIKASI SINYAL EMG BERBASIS JARINGAN SYARAF TIRUAN DAN DISCRETE WAVELET TRANSFORM
}

\author{
Ikhwan Mustiadi \\ Jurusan Teknik Elektro, Fakultas Sains dan Teknologi, Universitas Respati Yogyakarta ${ }^{1,2)}$ \\ Jl. Laksda Adisucipto, Km 6,3 Depok, Sleman, Yogyakarta 55281 \\ E-mail :ikhwan.unriyo@gmail.com
}

\begin{abstract}
Electromyograph signal (EMG) is a non-stationary biomedical signal, making it difficult to determine the pattern. The method normally used for signal analysis is Fast Fourier Transform (FFT), but it has some drawbacks because it requires stable signals. To answer this deficiency wavelet transformation is used, especially discrete wavelet transforms that can analyze the signal in both the realm of time and frequency.

The method to be used in this research is wavelet transformation for signal analysis with decomposition up to level 7 using wavelet symlet 8. This feature extraction result is used as input of artificial neural network (ANN) type of propagation backward with architecture of 8 input layer, 5 hidden layer and 3 layers of output.

ANN Turnback is able to recognize 3 types of EMG signals namely Normal, Myopathy and Neuropathy. Based on the feature extraction of EMG signal decomposition energy characteristics. Network architecture with 8 input layers. 5 hidden layers and 3 output layers Proven best in the introduction of EMG signals. The highest success rate is the introduction of EMop Myopathy signal pattern reaching $94 \%$, so the network architecture is proposed to regenerate the EMG signal.
\end{abstract}

Keyword: Electromyograph, Wavelet, Artificial Neural Network.

\section{PENDAHULUAN}

Otot adalah sebuah jaringan konektif dalam tubuh dengan tugas utamanya kontraksi. Kontraksi otot berfungsi untuk menggerakkan bagian - bagian tubuh dan substansi dalam tubuh. Menurut Rokhana dkk (2009) Ada tiga macam sel otot dalam tubuh manusia yaitu: jantung, lurik dan polos, namun yang berperan dalam pergerakan kerangka tubuh manusia adalah otot lurik.

Elektromiografi (EMG) adalah teknik yang berkaitan dengan pencatatan dan analisis sinyal mioelektrik. Menurut Bastiaensen (2007) Sinyal ini dibentuk oleh variasi dalam keadaan fisiologis dari membran serat otot. Setiap otot memiliki beberapa unit motorik yang terhubung ke serat otot. Unit motorik ini adalah kontrol syaraf sebenarnya dari otot. Teknik pengukuran EMG yang sering digunakan adalah surface Electromyograph (sEMG), yaitu teknik non-invasive untuk mengukur hasil aktivitas elektrik otot dari proses kontraksi dan relaksasi. Oleh karena itu penelitian tentang EMG merupakan bagian biomedical engineering yangtelah berkembang pesat, sebagai contoh yaitu penelitian yang dilakukan oleh Rokhana dkk (2009) yaitu aplikasi biosignal manusia untuk kontrol buatan pada manusia maupun untuk mendeteksi adanya kelainan aktivitas otot.

Analisis sinyal EMG menggunakan transformasi wavelet adalah salah satu alat pemrosesan sinyal yang paling baik sampai saat ini. Hal ini banyak digunakan dalam sistem pengenalan pola EMG. Phinyomark (2011) menggunakan ekstraksi fitur EMG dari beberapa tingkat dekomposisi wavelet dari sinyal EMG telah diteliti untuk tingkat yang berbeda, berbagai wavelet induk digunakan untuk memperoleh komponen resolusi sinyal EMG yang berguna. kemudian merekonstruksi sinyal EMG kembali untuk mengambil informasi yang berguna. 
Back Propagation Neural Network (BPNN) adalah salah satu cara untuk mengklasifikasi suatu sinyal atau informasi, dalam jaringan propagasi balik, setiap unit yang berada pada lapisan input terhubung dengan setiap unit yang ada pada lapisan tersembunyi. Setiap unit yang ada pada lapisan tersembunyi terhubung dengan setiap unit yang ada pada lapisan output. Jaringan ini terdiri atas banyak lapisan (multilayer network). Ketika jaringan diberikan pola masukan sebagai pola pelatihan, maka pola tersebut menuju unit-unit lapisan tersembunyi yang diteruskan pada unit-unit pada lapisan keluaran, kemudian unit-unit lapisan keluaran akan memberikan respon sebagai keluaran Jaringan Syaraf Tiruan (JST). Saat hasil keluaran tidak sesuai dengan yang diharapkan, maka keluaran akan disebarkan mundur (backward) ke lapisan tersembunyi kemudian dari lapisan tersembunyi menuju lapisan masukan (Puspitaningrum, 2006).

\subsection{Perumusan Masalah}

Klasifikasi sinyal EMG dengan tepat, sulit dilakukan, sehingga diperlukan keahlian dari seorang dokter yang berpengalaman dalam menentukan klasifikasi sinyal EMG ini. Rumusan masalah dalam penelitian ini adalah bagaimana membuat klasifikasi sinyal EMG untuk membedakan sinyal EMG normal dan yang memiliki kelainan dengan menggunakan metode Artificial Inteligent (AI) yaitu dengan BPNN dengan bantuan analisis Discrete Wavelet Transform(DWT).

\subsection{Tujuan Penelitian}

Tujuan penelitian ini adalah untuk dapat menganalisis dan mengklasifikasi sinyal EMG normal, neuropathy dan myopathy dengan menggunakan BPNN sebagai metode klasifikasinya dan DWT sebagai analisis isyaratnya. Dengan banyaknya kelainan masalah kelainan fungsi otot, diharapkan dapat memberikan kontribusi dalam penentuan kelainan otot pada dunia kesehatan.

\subsection{Batasan Masalah}

Permasalahan penelitian ini perlu dibatasi agar tetap pada tujuan penelitian ini. Klasifikasi yang dilakukan pada penelitian ini hanya menganalisis sinyal EMG menjadi normal, neuropathy dan myopathy tanpa menganalisis tingkat kelainan fungsi otot yang terjadi.

\subsection{Manfaat Penelitian}

Dengan menerapkan sistem AI yaitu BPNN untuk klasifikasi sinyal EMG diharapkan dapat memberikan kontribusi pada dunia kesehatan yang meliputi :

a. Bagi bidang medis: dapat memberikan data sebagai bahan untuk mengambil keputusan lebih tepat dalam diagnosa penyakit otot pasien.

b. Bagi masyarakat: dapat memberikan pengetahuan tentang sinyal EMG yang normal dan tidak normal khususnya Neuropathy dan Myopathy.

c. Bagi ilmu pengetahuan: dapat memberikan kontribusi pada metode sistem cerdas dan dapat digunakan sebagai literatur bagi peneliti selanjutnya untuk mengembangkan lebih jauh.

\section{TINJAUAN PUSTAKA}

Penelitian tentang sinyal elektrik otot EMG sudah pernah dilakukan sebelumnya yaitu: Mesin dan Farida (2004) melakukan pemodelan sinyal surface EMG untuk menggambarkan sinyal EMG yang dihasilkan oleh otot rangka, yaitu otot yang memiliki dua kelompok serat dengan dua orientasi (inhomogen) dengan menggunakan Transformasi Fourier. Penelitian selanjutnya dilakukan oleh Pauk (2008) dengan membandingkan beberapa metode untuk akuisisi sinyal EMG dengan filter yang tepat dan pengolah data yang baik, dari beberapa jenis filter dan pengolah sinyal didapatkan yang terbaik dengan filter butterword, Transformasi Wavelet sebagai pengolah isyaratnya, kemudian dimodelkan. 
Penelitian serupa dilakukan oleh Kale and Dudul (2009) untuk mereduksi derau dengan metode Focused Time-Lagged Recurrent Neural Network (FLTRNN). Hasil penelitian menunjukkan bahwa model yang diusulkan FTLRNN optimal memiliki MSE 0,000067 dan koefisien korelasi 0,000048 setinggi 0,99950 dan 0,99939 untuk sinyal derau dan sinyal EMG, ketika divalidasi pada uji datasheet. Penelitian selanjutnya dilakukan oleh (Berger dkk, 2008) yang menyajikan investigasi menyeluruh kepraktisan menggunakan model Autoregressive (AR) dan Wavelet Neural Network (WNN) untuk mengekstrak fitur yang akan diklasifikasikan dari sinyal EMG. Teknik - teknik yang diusulkan berhasil diterapkan dalam klasifikasi dan dekomposisi sinyal EMG yang direkam dari normal (NOR), penderita miopati (MYO) dan gangguan neurogenic (NEU). Dengan menggunakan AR PSD dan WNN memberikan persentase klasifikasi terbaik dibandingkan dengan metode feed forward error back propagation artificial neural networks (FEBANN).

Penelitian tentang klasifikasi EMG menggunakan Wavelet dan Neural network juga pernah dilakukan dengan menggunakan sebuah pendekatan untuk pemrosesan sinyal EMG berdasarkan Artificial Neural Network (ANN) dan DWT untuk melakukan analisis otomatis menggunakan komputer pribadi. Neural Networks diperkenalkan untuk memecahkan masalah pengenalan pola yang berbeda untuk sinyal EMG (Mallat, 1999).

\subsection{Landasan Teori}

\subsubsection{Sinyal Biomedis}

Unit motor adalah motoneuron bersama dengan axon dan seluruh otot yang diinervasinya. Pada saat sebuah motoneuron beraksi, seluruh serabut syaraf yang diinervasinya berkontraksi. Satu serabut syaraf dapat menginervasi banyak cabang. Serabut - serabut otot yang berasal dari satu motor unit tersebar merata diotot. Ujung cabang - cabang motoneuron bersama dengan membran otot yang diinervasinya membentuk motor end plate (junction neuromuscularis). Sehingga dapat disimpulkan bahwa psikologi kontraksi dan konduksi otot dikontrol oleh :

1. Aktifitas dari motor unit dengan otot.

2. Mengontrol frekuensi dari rangsangan motor neuron dari masing - masing motor unit.

\subsubsection{Sinyal EMG}

Sinyal elektrik adalah besaran elektrik terukur yang berubah dalam waktu dan atau dalam ruang, serta membawa informasi. Besaran ini bisa merupakan besaran elektrik murni (tegangan, arus, dll), tetapi pada umumnya adalah besaran fisik lain yang dijadikan elektrik dengan bantuan sensor.

Electromyogram adalah teknik untuk mengevaluasi dan merekam aktifitas sinyal otot, aktifitas electromyogram ditunjukkan oleh electromyography. Electromyograph berfungsi untuk mendeteksi adanya potensial listrik yang dihasilkan oleh otot saat kontraksi dan relaksasi (Phinyomark, 2009).

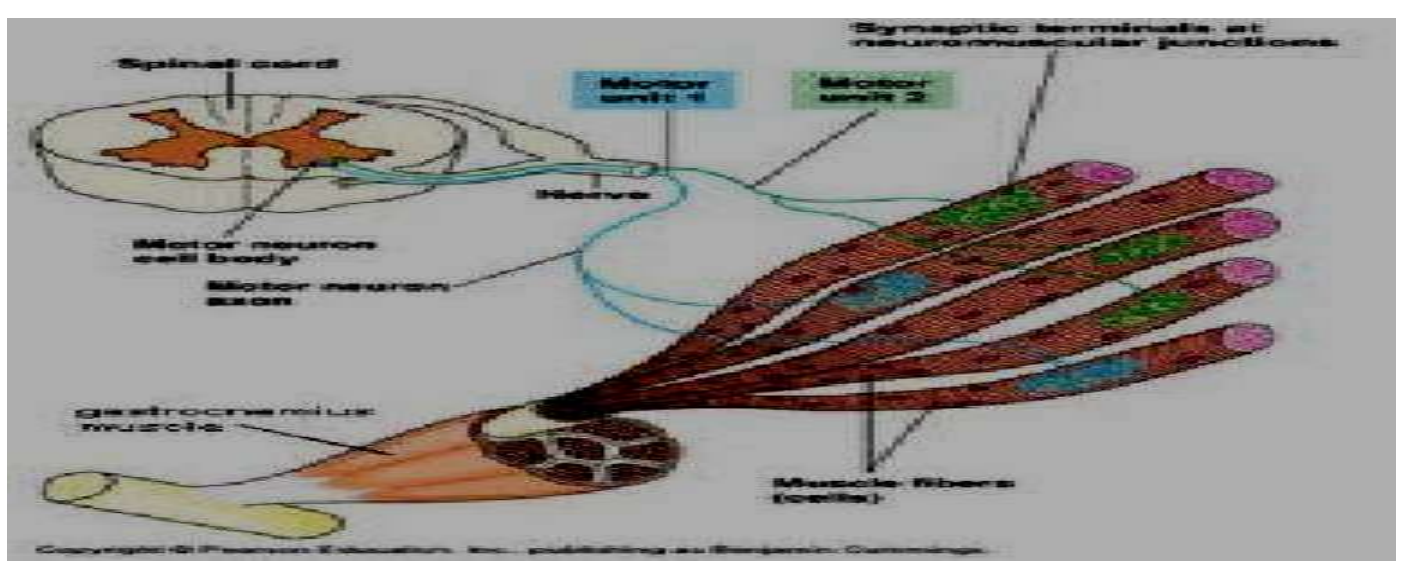

Gambar 1. Contoh Motor Unit Pada Otot. 


\subsubsection{Myopathy}

Dalam terminologi kedokteran miopati merupakan penyakit neuromuskuler dimana serat - serat otot tidak berfungsi sebagaimana mestinya, ditandai dengan terjadinya kelemahan otot. Namun demikian kram otot, kekakuan dan spasme dapat juga dihubungkan dengan miopati (Suhaimi, 2003).

Miopati adalah kumpulan kelainan pada otot yang biasanya tanpa melibatkan sistem saraf dan tidak berhubungan sama sekali dengan gangguan pada jembatan neuromuskuler. Distrofi otot adalah bentuk kelainan yang paling umum didapati dan Duchenne Distrofi Muscular (DMD) adalah jenis distrofi otot yang paling sering ditemui. Distrofi otot atau Muscular Dystrophy (MD) adalah penyakit otot turunan di mana seratserat otot sangat rentan rusak. Otot, terutama otot-otot sukarela, menjadi semakin lemah. Pada tahap akhir distrofi otot, lemak dan jaringan ikat sering menggantikan serat otot.

\subsubsection{Neuropathy}

Neuropathy adalah suatu penyakit dengan gejala klinik yang timbul karena kelainan syaraf perifer, umumnya berupa degenerasi non inflamasi yang luas dengan gejala yang meliputi kelemahan motorik, gangguan sensorik, gangguan autonom dan melemahnya reflek tendon. Syaraf perifer yang terkena meliputi semua akar syaraf spinalis, sel ganglion radiks dorsalis, semua syaraf perifer dengan semua cabang terminalnya, susunan syaraf autonom dan syaraf otak kecuali syaraf optikus dan olfaktorius. Penyebab dari neuropati sangat banyak diantaranya adalah proses inflamasi, kelainan endokrin dan metabolik, infeksi, disproteinemia, vaskulitis, defesiensi nutrisi, toksin, obat - obatan dan idiopatik. Degenerasi selubung mielin sebagai akibat dari kelainan pada akson disebut degenerasi Walleri.

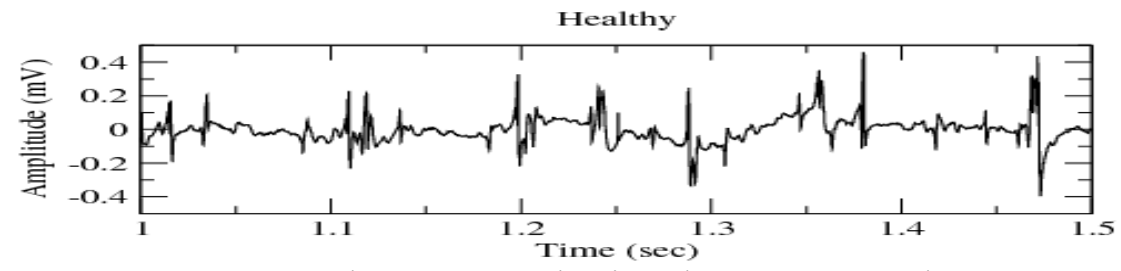

Gambar 2. Contoh Sinyal EMG Normal.

(www.physionet.org)

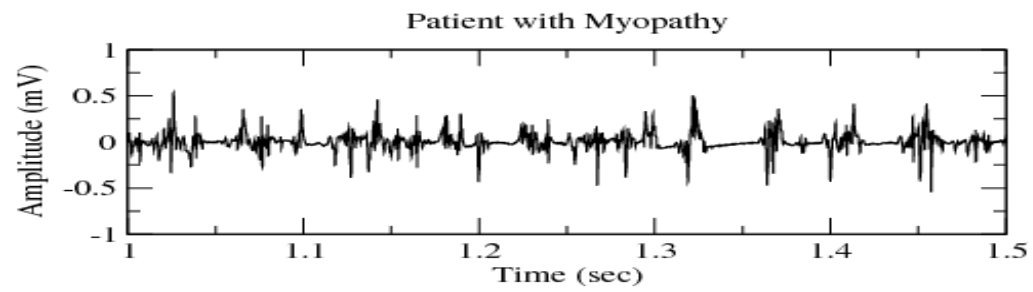

Gambar 3. Sinyal EMG Myopathy.

(www.physionet.org)

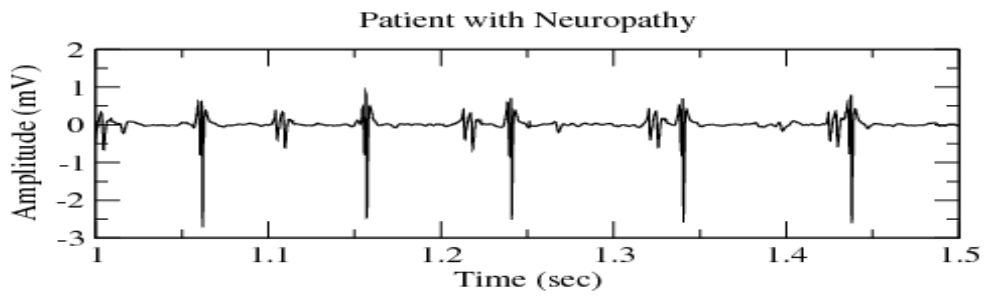

Gambar 4. Sinyal EMG Neuropaty.

(www.physionet.org) 


\subsubsection{Energi Sinyal}

Sebagian besar sinyal (sinyal listrik) adalah sinyal teganan atau arus listrik. Energi yang dikeluarkan oleh suatu tegangan listrik pada sebuah resistor selama rentang waktu tertentu dinyatakan dengan persamaan (Mallat S, 1999).

$E=\int_{t 1}^{t 2} \frac{v(t)^{2}}{R} d t$ Wattdetik

Begitu juga arus listrik, energi disipasi sinyal oleh arus listrik adalah :

$E=\int_{t 1}^{t 2} R i^{2} d t$ Wattdetik

Pada kedua persamaan diatas, energi tampak berbanding lurus dengan integral kuadrat sinyal. Jika hambatan (R) diatur sama dengan $1 \mathrm{ohm}$, maka persamaan 1 dan 2 dapat dituliskan dalam bentuk lebh umum berikut :

$E=\int_{-\infty}^{+\infty} x^{2}(t) d t \prec \infty$

Jika sinyal $\mathrm{x}(\mathrm{t})$ kontinu menjadi sinyal diskrit $\mathrm{x}(\mathrm{n})$, maka persamaan energi sinyal menjadi,

$$
E=\sum_{-\infty}^{\infty} x^{2}(n)
$$

Untuk sinyal diskrit yang panjangnya $\mathrm{N}$ maka persamaan 4 dapat ditulis,

$$
E=\sum_{n=0}^{N-1} x^{2}(n), \mathrm{n}=0,1,2, \ldots ., \mathrm{N}-1
$$

\subsubsection{Transformasi Wavelet Diskrit}

Definisi Wavelet (secara harfiah adalah gelombang singkat) adalah himpunan fungsi dalam ruang vektor $\mathrm{L}^{2} \mathrm{I}$, yang mempunyai sifat sebagai berikut :
1. Berenergi terbatas.

2. Merupakan fungsi bandpass pada domain frekuensi.

3. Merupakan hasil penggeseran (translasi) dan penskalaan (dilatasi) dari sebuah fungsi induk (Mallat S, 1999 dan Subasi A, etc, 2006) yaitu :

$\psi_{a, b}(\hat{t})=\frac{1}{\sqrt{a}} \psi\left(\frac{t-b}{a}\right)$

dengan $\mathrm{a}, \mathrm{b} \in \mathrm{R}$ (bilangan nyata) dan $\mathrm{a} \neq 0$. Dalam hal ini a adalah parameter penskala dan $b$ adalah parameter penggeser posisi terhadap sumbu t. Faktor normalisasi $|a|^{1 / 2}$ digunakan untuk memastikan bahwa :

$\left|\psi_{a, b}\left(t^{2}\right)\right|=\left|\psi\left(t^{2}\right)\right|$

Pada transformasi Wavelet kontinyu, waktu $\mathrm{t}$ serta parameter penskala a dan penggeser $b$ berubah secara kontinyu (dengan $a \neq 0$ ). Pada Transformasi Wavelet kontinyu fungsi $\mathrm{f}(\mathrm{t})$ didefinisikan dengan :

$$
\begin{aligned}
& T W K_{f}(a, b)=\left\langle\psi_{a, b}(t), f(t)\right\rangle \\
& =\int_{-\infty}^{\infty} \psi_{a, b}(t) f(t) d t \\
& =\frac{1}{\sqrt{|a|}} \int_{-\infty}^{\infty} \psi\left(\frac{t-b}{a}\right) f(t) d t \ldots \ldots . .
\end{aligned}
$$

Transformasi Wavelet Kontinyu ini mempunya dua kelemahan, yaitu redundancy dan ketidak praktisan (impracticility). Masalah tersebut dapat diselesaikan dengan mendiskritkan parameter a dan b. Pada transformasi yang bersifat semi diskrit dilakukan pendiskritan terhadap parameter a dan $b$, dengan $a=a_{0}{ }^{j}$ dan $\mathrm{b}=\mathrm{a}_{0}{ }^{\mathrm{j}} \cdot \mathrm{k} \mathrm{b}_{0}$ dimana $\mathrm{j}$ dan $\mathrm{k}$ bilangan bulat, serta $\mathrm{a}_{0}>1$ dan $\mathrm{b}_{0}>0$. Pemilihan nilai $\mathrm{a}_{0}$ dan $\mathrm{b}_{0}$ bergantung pada Wavelet $\psi$ yang berkaitan dengan :

$$
\begin{aligned}
& \psi_{j, k}(t)=\frac{1}{\sqrt{\alpha_{0}^{j}}} \psi\left(\frac{t-k b_{0} \alpha_{0}^{j}}{\alpha_{0}^{j}}\right) \\
& =\frac{1}{\sqrt{a_{0}^{j}}} \psi\left(\frac{t}{a_{2}^{j}} k b_{0}\right) \ldots \ldots \ldots \ldots \ldots \ldots \ldots \ldots \ldots \ldots \ldots
\end{aligned}
$$


Pendiskritan a dan $\mathrm{b}$ menghasilkan Runtun Wavelet (RW), yaitu :

$$
R W\left(a_{0}^{l} a_{0}^{j} b b_{0}\right)=\frac{1}{\sqrt{a_{0}^{l}}} \int^{\infty} \psi\left(\frac{t}{a_{0}^{3}}-k b_{0}\right) f(t) d t \ldots \ldots
$$

Dengan membuat waktu $\mathrm{t}$ menjadi diskrit maka diperoleh DWT, yaitu :

$$
\operatorname{DWT}\left(a_{v}^{j}, a_{v}^{j} k b_{0}\right)=\frac{1}{\sqrt{a_{0}^{j}}} \sum_{n} \psi\left(\frac{t}{a_{0}^{j}}-k b_{0}\right) f(n)
$$

Untuk $\mathrm{a}_{0}=2$ dan $\mathrm{b}_{0}=1$, Wavelet -nya disebut dyadic, yaitu:

$$
\psi_{j, k}(t)=\frac{1}{\sqrt{2 j}} \psi\left(\frac{t}{2 j}-k\right)
$$

DWT nya menjadi :

$$
D W T_{d y}\left(2^{j}, 2^{j} k\right)=2^{j / 2} \sum_{n} \psi\left(2^{j_{n}}-k\right) f(n)
$$

Sinyal masukan S dilewatkan melalui 2 filter komplementer LPF, HPF dan downsampling dengan membuang setiap data dari keduanya, sehingga diperoleh koefisien pendekatan cA (komponen frekuensi rendah) dan koefisien detil cD (komponen frekuensi tinggi).

Dekomposisi wavelet adalah teknik untuk menguraikan sinyal menjadi koefisien detail dan koefisien koefisien aproksimasi seperti dibahas didepan dengan menggunakan HPF dan LPF dan down sampling (Mallat S, 1999).

\section{a. Daubechies, Symlet dan Coiflet}

Wavelet Daubechies secara historal berasal dari Haar Wavelet. Daubhechies didukung secara kompak oleh induk wavelet $\psi$ dan fungsi skala $\varphi$ dalam interval $\{0,2 \mathrm{~N}$ 1) dengan $\mathrm{N}$ bilangan bulat $\geq 1$ dan mempunyai sifat sebagai berikut :

1. Fungsi $\psi$ mempunyai sejumlah tertentu momen nol, yaitun :
a. $\int_{-\sim} t^{2} \psi(t) d t=0$

Untuk $\mathrm{k}=0,1,2,3 \ldots, \mathrm{N}-1$

2. Mempunyai konjugasi kuadrat bentuk dekomposisi LPF dan HPF berhingga, yang memungkinkan untuk mengoptimalkan perhitungan koefiisen wavelet dengan algoritma dekomposisi dari S Mallat (Mallat S, 1999).

Selanjutnya, Ingrid Deubhecis mencoba memodifikasi wavelet yang telah dibentuknya menjadi lebih simetrik dengan tanpa meningggalkan kesederhanaan yang telah dimiliki sistem sehingga dikatakan sebagai Wavelet Symlet dengan memiliki sifat yang sama dengan wavelet Deubhechies. Coiflet dikembangkan juga oleh Daubechies yang mengamati suatu hal yang tidak biasa dimana fungsi $\psi$ pada pengembangan wavelet sebelumnya memiliki moment $2 \mathrm{~N}$ yang sama dengan 0 dan fungsi $\varphi$ juga memiliki momen $2 \mathrm{~N}-1$ yang sama dengan 0 .

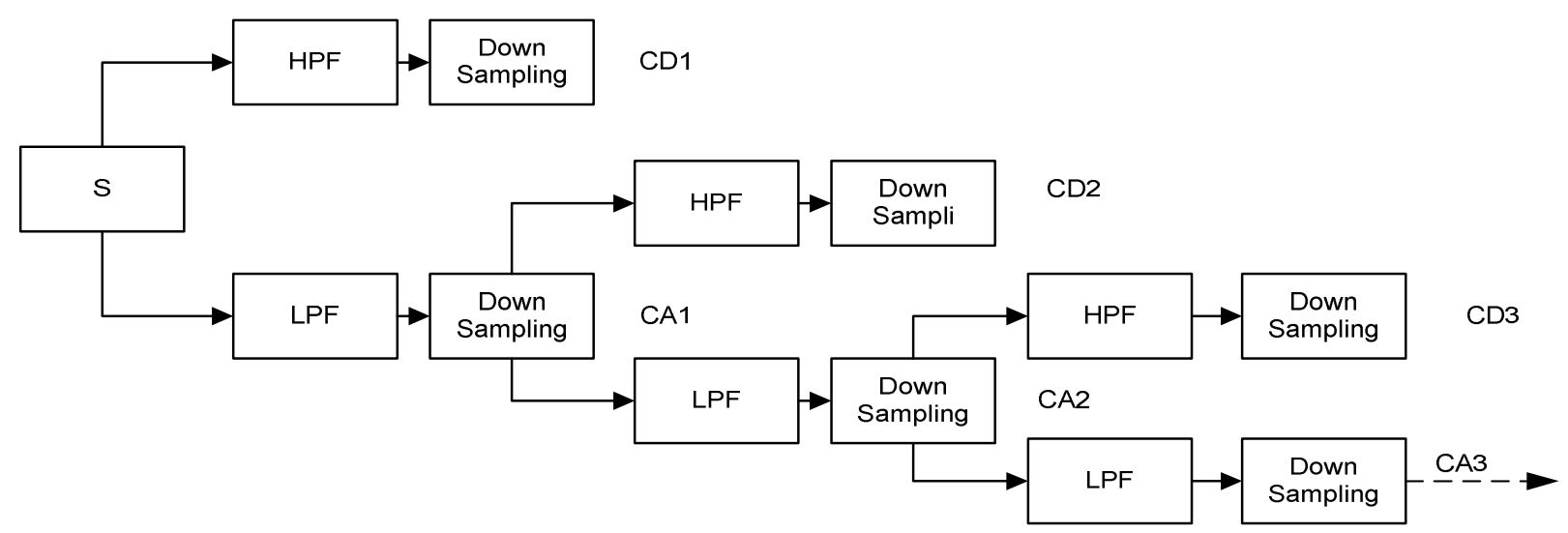

Gambar 5. Dekomposisi Wavelet. 


\section{b. Jaringan Syaraf Tiruan (JST)}

JST atau Neural Network adalah suatu metode komputasi yang meniru sistem jaringan syaraf biologis. Metode ini menggunakan elemen perhitungan tak-linear dasar yang disebut neuron yang diorganisasikan sebagai jaringan yang saling berhubungan, sehingga mirip dengan jaringan syaraf manusia. JST dibentuk untuk memecahkan suatu masalah tertentu seperti pengenalan pola atau klasifikasi karena proses pembelajaran. JST juga merupakan sistem yang bersifat "fault tolerant" dalam 2 hal. Pertama, dapat mengenali sinyal input yang agak berbeda dari yang pernah diterima sebelumnya. Kedua, tetap mampu bekerja meskipun beberapa neuron-nya tidak mampu bekerja dengan baik. Jika sebuah neuron rusak, neuron lain dapat dilatih untuk menggantikan fungsi neuron yang rusak (Puspitaningrum, 2006).

Keterbatasan jaringan neural satu lapis dalam pemetaan dapat diatasi oleh jaringan multi lapis, karena dapat belajar setiap pemetaan kontinyu dengan akurasi yang lebih baik. Jaringan multi lapis dapat menggunakan metode pelatihan yang merambatkan balik galat yang merupakan metode penurunan gradien. Jaringan yang menggunakan metode pelatihan seperti ini disebut jaringan perambatan balik (Kusumadewi. S, 2004). Pelatihan jaringan perambatan balik melibatkan tiga langkah :

1. Umpan maju pola pelatihan masukan.

2. Perhitungan dan perambatan balik galat terkait.

3. Pengaturan bobot.

\section{c. Arsitektur}

Jaringan neural multi lapis dengan satu lapis unit tersembunyi terlihat pada gambar 7, Unit keluaran dan tersembunyi mempunyai prasikap (bias) yang berlaku sebagai bobot koneksi dari unit yang keluarannya selalu satu.

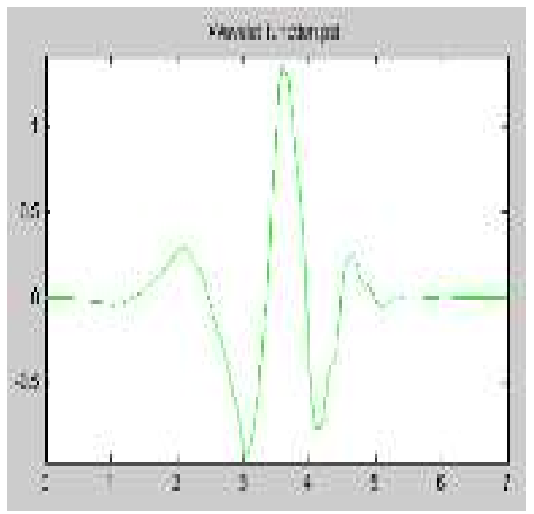

a. Deubechies

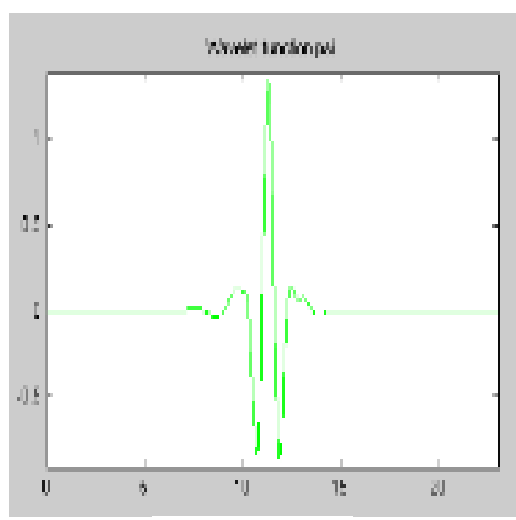

b. Symlet

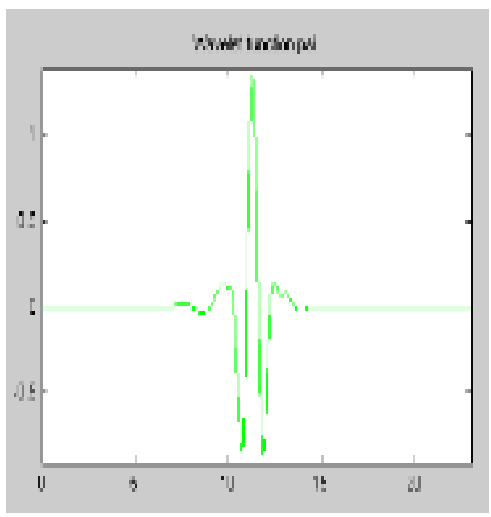

c. Cioflet

Gambar 6. Keluarga Wavelet Ortogonal.

1

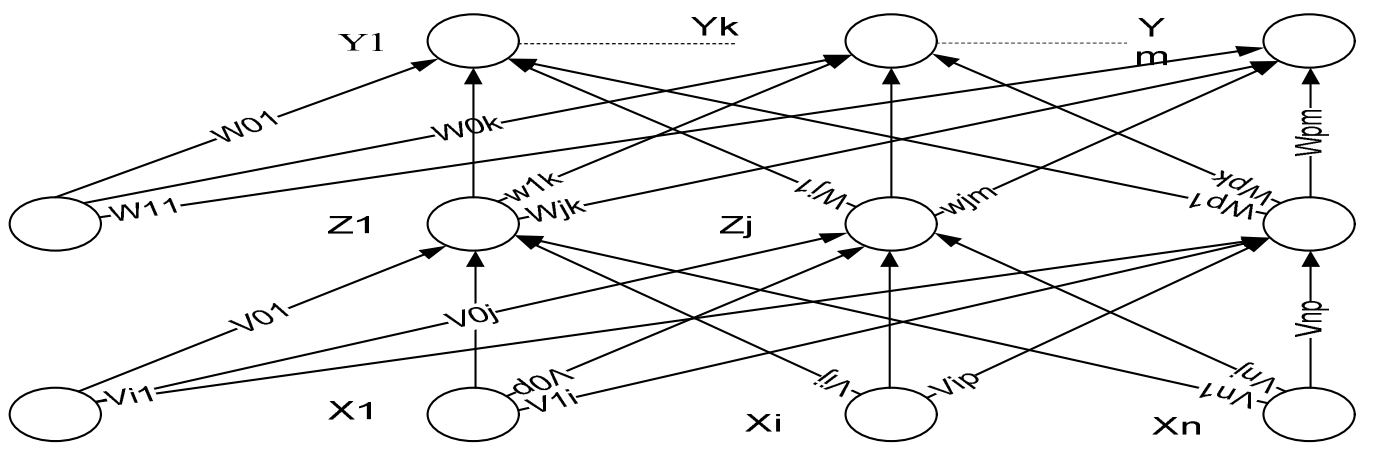

Gambar 7. Jaringan Neural Perambatan Balik

(Fausset. L, 1994) 
Tabel 1. Spesifikasi Teknis Sinyal EMG

\begin{tabular}{c|c|c|c|c|c}
\hline Jenis & $\begin{array}{c}\text { Frekuensi } \\
\text { Sampling (Hz) }\end{array}$ & $\begin{array}{c}\text { Periode } \\
\text { Sampling (s) }\end{array}$ & $\begin{array}{c}\text { Lama } \\
\text { Rekaman (s) }\end{array}$ & Base (mV) & Gain (mV) \\
\hline Sehat & 4000 & 0.00025 & 10 & 0 & 10000 \\
Myopathy & 4000 & 0.00025 & 10 & 0 & 10000 \\
Neuropathy & 4000 & 0.00025 & 10 & 0 & 10000 \\
\hline
\end{tabular}

\section{METODOLOGI PENELITIAN}

\subsection{Bahan Penelitian}

Penelitian ini menggunakan 3 jenis sinyal EMG yang diperoleh dari Phisionet. Sinyal EMG normal menggunakan Pengambilan data yang dilakukan pada pasien 42 tahun tanpa adanya riwayat penyakit neuromuskular. Sinyal EMG Neuropathy diambil pada pasien berusia 62 tahun dengan nyeri punggung kronis dan neuropati karena radikulopati kanan. Sedangkan sinyal EMG Myopathy diambil dari pasien berusia 57 tahun dengan myopathy, karena sejarah lama dari polymyositis. Diobati dengan steroid dan metotreksat dosis rendah (Suhaimi, 2003).

\section{a. Spesifikasi Data EMG Dari Physionet}

Sinyal EMG yang digunakan pada penelitian ini adalah sinyal yang berasal dari physionet.org data dikumpulkan dengan Medelec Synergy N2 Monitoring System (Oxford Instruments Medical, Old Woking, United Kingdom). Data kemudian dikumpulkan selama beberapa detik. Data yang tercatat sebesar $50 \mathrm{KHz}$ dan kemudian di down sampling sampai $4000 \mathrm{~Hz}$. Selama proses perekaman digunakan dua filter analog : high-pass filter $20 \mathrm{~Hz}$ dan low-pass filter $5 \mathrm{~K} \mathrm{~Hz}$ (Suhaimi, 2003). Spesifikasi teknis data sinyal EMG yang diperoleh dari Physionet secara lengkap disajikan pada tabel 1.

Frekuensi sampling yang digunakan oleh physionet adalah $4000 \mathrm{~Hz}$, lama periode sampling untuk setiap data adalah 0,00025 detik. Perekaman dilakukan selama 10 detik, menggunakan gain 10000 kali (Suhaimi, 2003).
Untuk mendapatkan sinyal asli EMG adalah dengan persamaan :

$\mathrm{EMG}_{\text {real }}=\left(\mathrm{EMG}_{\text {sample }}-\right.$ Base $) /$ Gain

Karena Base dari ketiga sinyal tersebut adalah 0, maka persamaan 15 dapat disederhanakan menjadi :

$\mathrm{EMG}_{\text {real }}=\mathrm{EMG}_{\text {sample }} /$ Gain

\section{b. Variasi Sinyal EMG Sebagai Bahan Penelitian}

Bahan yang digunakan pada penelitian ini adalah 3 jenis sinyal yang berbeda dari Physionet.org yaitu sinyal EMG Sehat, Sinyal EMG Myopathy dan sinyal EMG Neuropathy. Karena hanya tersedia 3 jenis sinyal dan masing - masing sinyal hanya ada 1, maka pada penelitian ini, penulis melakukan variasi sinyal EMG dengan menambahkan derau pada masing - masing sinyal. Masing - masing sinyal divariasi menjadi 10 sinyal baru yang akan dijadikan bahan uji jaringan, sedangkan 3 jenis sinyal asli akan dijadikan sebagai data latih jaringan.

\subsection{Alat Penelitian}

\section{a. Matlab}

Alat yang digunakan dalam penelitian ini adalah program Matlab (Matrix Laboratory) yang merupakan suatu perangkat lunak matematis menggunakan matrix dan vektor sebagai elemen data utama. Matlab merupakan tool matematis yang sangat kompleks saat ini. 


\section{b. Discrete Wavelet Transform}

Wavelet adalah salah satu alat untuk menganalisis sebuah sinyal elektrik, wavelet menerapkan beberapa filter dalam analisisnya, yaitu High Pass Filter dan Low Pass Filter secara bersamaan. Dengan membagi sinyal ke dalam bentuk koefisien wavelet dengan melakukan dekomposisi sinyal wavelet dan sinyal wavelet dapat direkonstruksi dengan tingkat error yang sangat kecil. Pemilihan jenis wavelet dalam penelitian ini adalah dengan metode eksperimen, sehingga didapatkan error rekonstruksi terkecil dalam menyusun kembali sinyal menjadi sinyal aslinya. Pada penelitian ini, penulis membandingkan antara wavelet duebechis dan wavelet symlet dengan beberapa tingkatan.

\section{c. Back Propagation Neural Network}

Back propagation adalah salah satu metode yang digunakan untuk melakukan klasifikasi terhadap sesuatu. Pada penelitian ini, back propagation digunakan untuk mengenali pola dari sinyal EMG Normal,
Myopathy dan Neuropathy. Dengan menggunakan sebuah Hidden Layer.

\subsection{Jalan Penelitian}

Diagram skema jalannya penelitian seperti pada gambar 8. Ada beberapa tahapan dalam penelitian yaitu :

\section{- Tahap Persiapan Data EMG}

Data EMG yang digunakan adalah data dari physionet, kemudian divariasi menjadi 10 sinyal untuk setiap jenisnya dengan menambahkan derau.

- Tahap Pemilihan Fungsi Wavelet Pada tahap ini dipilih fungsi Wavelet yang memiliki error rekonstruksi terkecil untuk sinyal yang akan diteliti, pemilihan fungsi wavelet ini sangat penting, karena akan mempengaruhi keakuratan dalam pengenalan pola pada tahap klasifikasi sinyal EMG. Pada penelitian ini dipilih fungsi Wavelet dengan mencoba dua fungsi Wavelet, yaitu Deubechies dan Symlet.

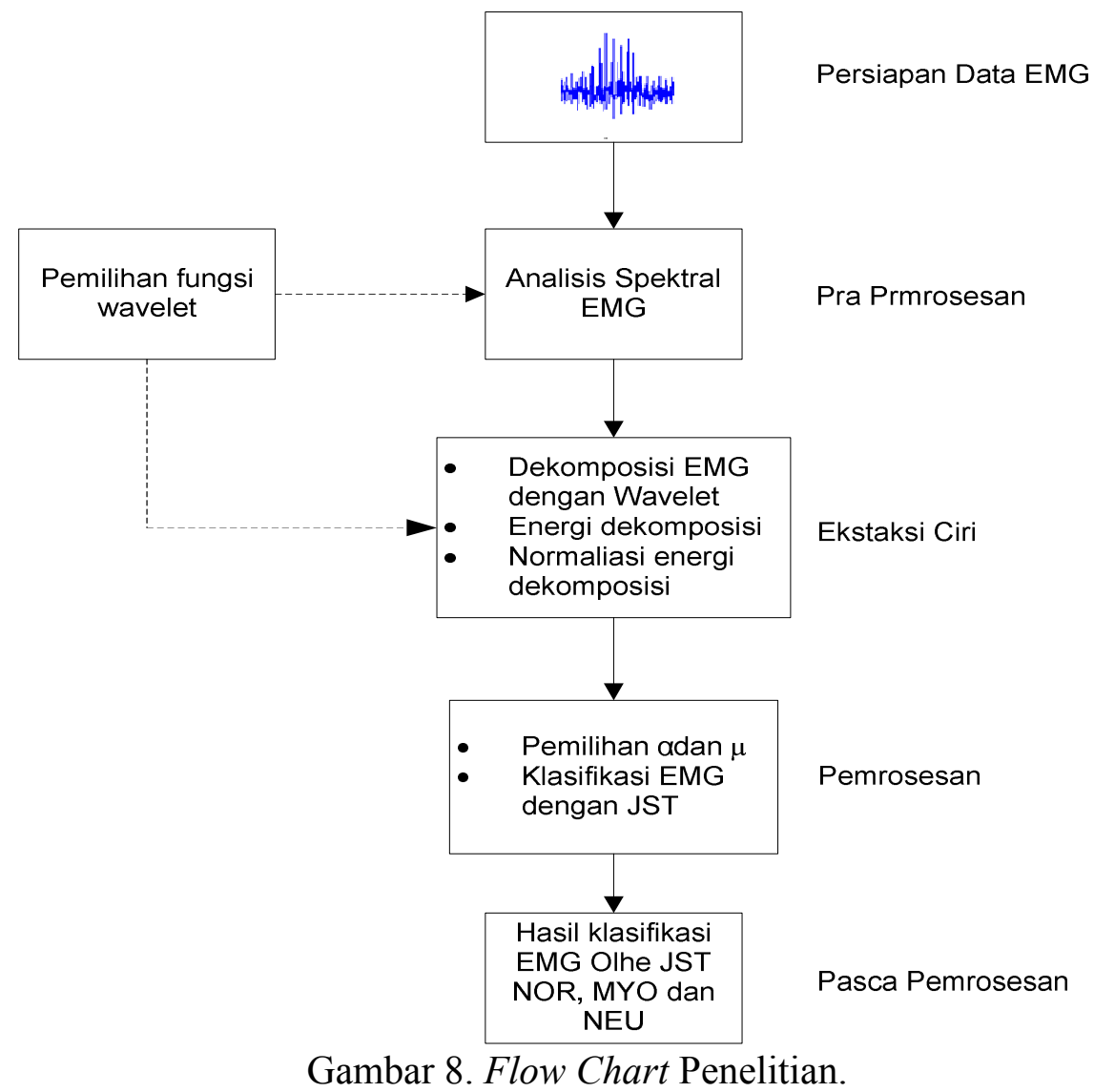


Tabel 2. Rentang Frekuensi Masing - Masing Tingkat Dekomposisi Wavelet

\begin{tabular}{c|c}
\hline \multicolumn{2}{c}{ Semua EMG Fs $=\mathbf{4 0 0 0 ~ H z}$} \\
\hline Sub-band & Range frekuensi (Hz) \\
A5 & $0-15,875$ \\
D7 & $15,875-31,75$ \\
D6 & $31,75-62,5$ \\
D5 & $62,5-125$ \\
D4 & $125-250$ \\
D3 & $250-500$ \\
D2 & $500-1000$ \\
D1 & $1000-2000$ \\
\hline
\end{tabular}

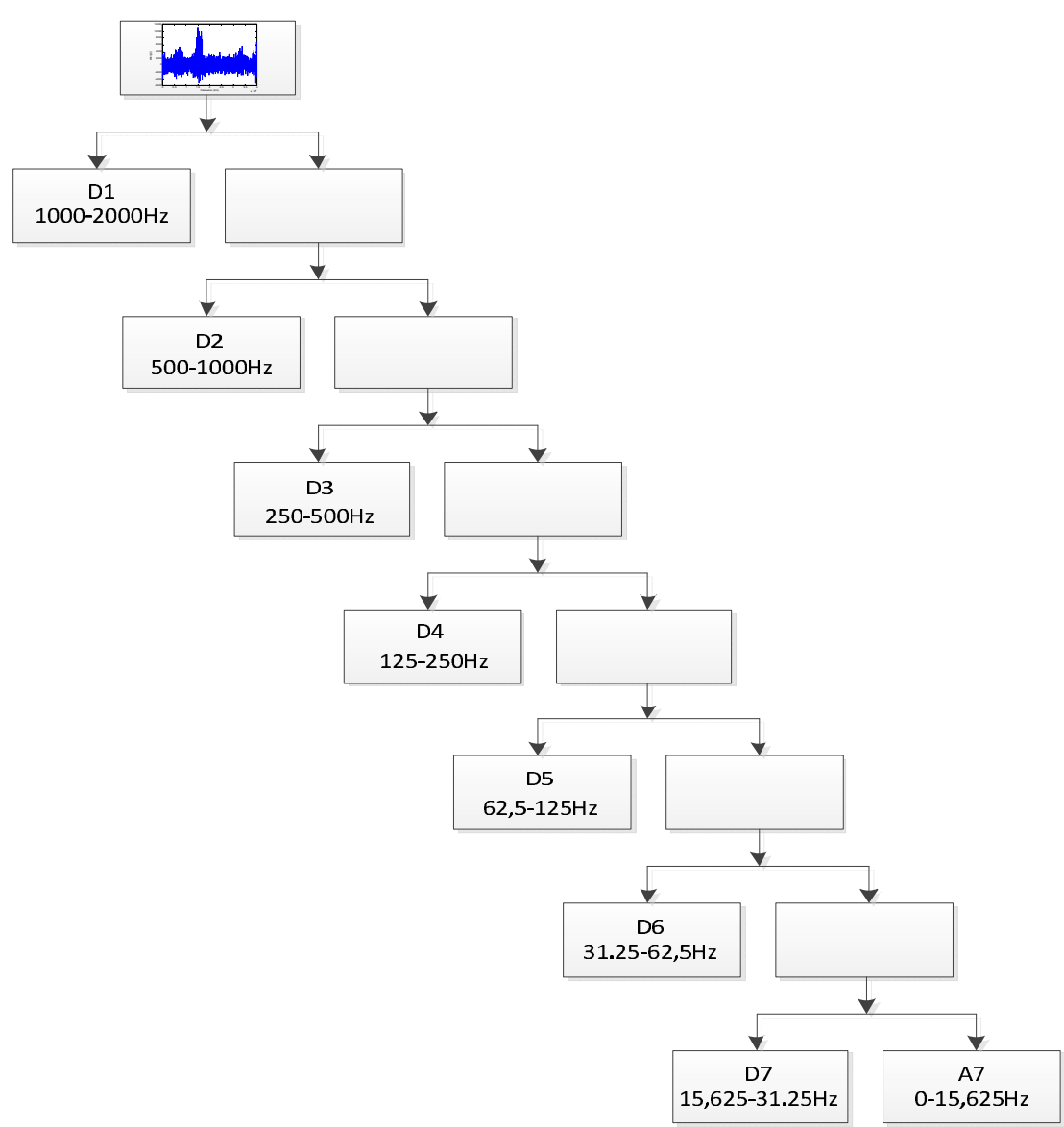

Gambar 9. Dekomposisi 7 Tingkat Sinyal EMG.

\section{- Tahap Ekstraksi Ciri}

Bertujuan untuk mendapatkan ciri yang unik dari seiap sinyal yang diteliti. Jenis sinyal yang dimaksud adalah sinyal otot NOR, MYO dan NEU. Sedangkan ciri yang diekstraksi dari sinyal EMG adalah sinyal yang sudah dinormalisasi. Untuk mendapatkan parameter ekstraksi ciri, sinyal EMG didekomposisi hingga 8 tingkat dengan menggunakan Transformasi Wavelet.
Energi dekomposisi adalah ilustrasi dekomposisi sinyal EMG 7 tingkat dengan frekuensi cuplik $4000 \mathrm{~Hz}$ seperti pada gambar 9. Dengan melakukan dekomposisi sinyal EMG, maka diperoleh komponenkomponen detail dari sinyal yaitu D1, D2, D3, D4, D5, D6, D7 dan sebuah sinyal aproksimasi yaitu A7. Masing - masing sinyal detail pada tiap tingkat dan sinyal aproksimasi pada tingkat terakhir dihitung energi dekomposisi reratanya dan 
dinormalisasi sebagai ekstraksi ciri sinyal EMG.

$\mathrm{E}_{\mathrm{Di}}=\Sigma\left(\mathrm{D}_{\mathrm{i}}(\mathrm{k})\right)^{2} /$ panjang $\mathrm{D}_{\mathrm{i}}, \mathrm{k}=1,2, \ldots$ panjang $\mathrm{D}_{\mathrm{i} .} \mathrm{i}=1,2, \ldots \mathrm{N}=7$.

Energi dekomposisi rerata sinyal aproksimasi A7 dihitung dengan persamaan :

$\mathrm{E}_{\mathrm{A} 7}=\Sigma\left(\mathrm{A}_{7}(\mathrm{k})\right)^{2} /$ panjang

$\mathrm{A}_{7}, \mathrm{k}=1,2$, panjang $\mathrm{A}_{7=7}$

Rentang frekuensi masing - masing tingkat atau sub-band seperti pada tabel 2.

Normalisasi energi dekomposisi yaitu masing - masing energi dekomposisi rerata kemudian dinormalisasi sehingga rentang nilainya antara 0 dan 1 dengan persamaan berikut :
$\mathrm{EN}_{\mathrm{j}}=\mathrm{E}_{\mathrm{i}} /$ maks $\left(\mathrm{ED}_{1}, . ., \quad \mathrm{EA}_{5}\right), \quad \mathrm{j}=$ $1,2,3, \mathrm{M}=6$.

Energi rerata yang dinormalisasi dari tiap dekomposisi ini (berjumlah 8) menjadi input JST jenis perambatan balik untuk mengenali pola sinyak EMG.

Tahap Pemrosesan adalah proses klasifikasi menggunakan jaringan syaraf tiruan perambatan balik. Struktur jaringan syaraf tiruan terdiri atas lapisan input, lapisan tersembunyi dan lapisan output.

Menurut Shibata dan Ikeda (2009), perkiraan jumlah neuron pada lapisan tersembunyi $\mathrm{N}_{\mathrm{h}}$ JST perambatan balik bergantung pada jumlah neuron input $\mathrm{N}_{1}$ dan jumlah neuron output $\mathrm{N}_{\mathrm{o}}$ dengan persamaan $N_{h}=\sqrt{N_{i} N_{0}}$

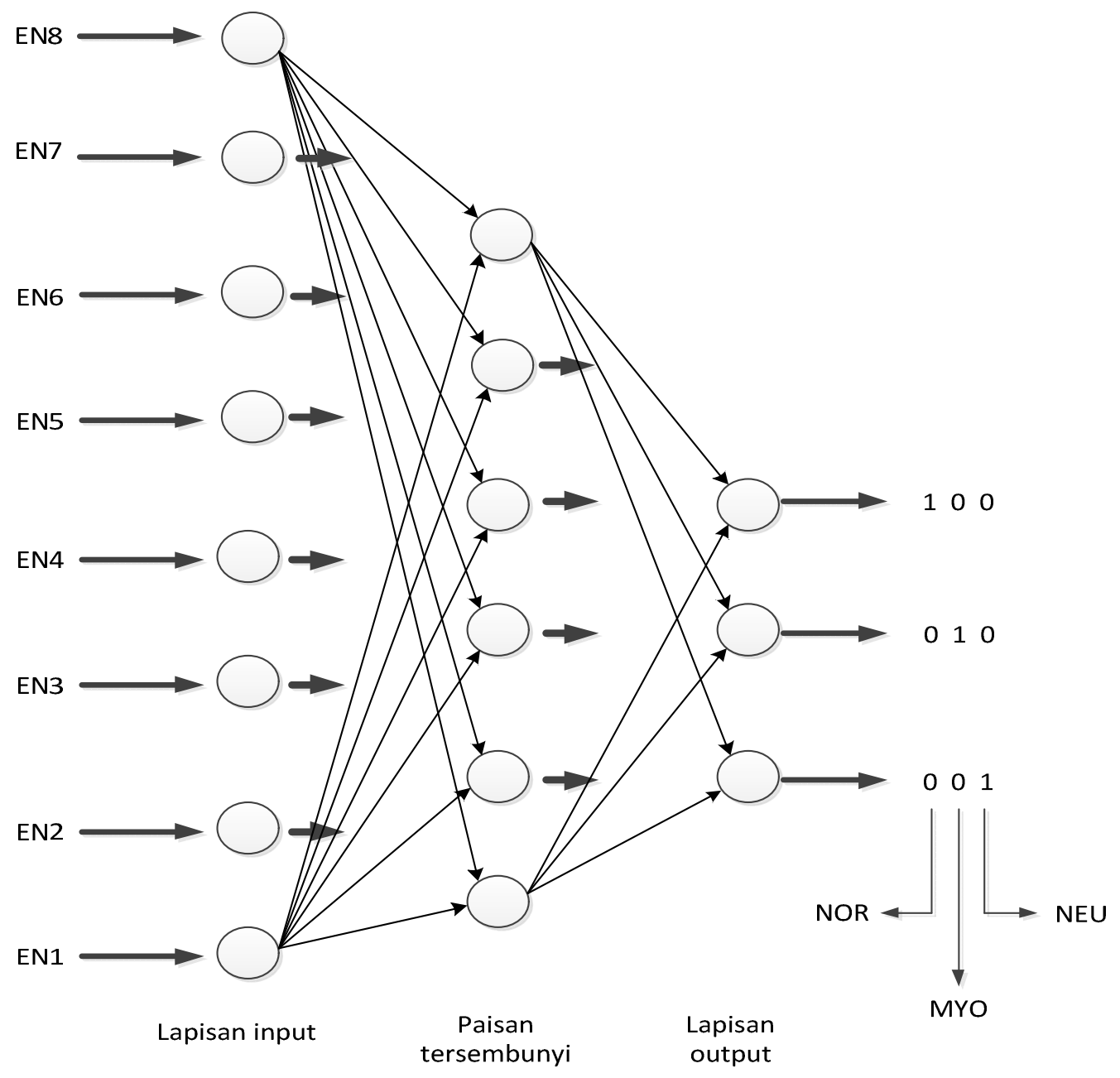

Gambar 10. Arsitektur JST Untuk Mengenali Pola Sinyal EMG. 
Pada penelitian ini $\mathrm{N}_{\mathrm{i}}=8$ dan $\mathrm{N}_{\mathrm{o}}=3$ sehingga jumlah neuron lapisan tersembunyi $\mathrm{N}_{\mathrm{n}}=\sqrt{8 \times 3}=\sqrt{24}=5$. pada penelitian ini juga dilakukan eksperimen untuk mendapatkan hasil pengenalan pola yang terbaik dengan membandingkan jumlah hidden layer, yaitu dengan jumlah 5, 6 dan 7 buah. Hasil terbaik adalah dengan 5 hidden layer. Unit keluaran terdiri atas 3 neuron sesuai dengan banyaknya EMG yang digunakan dengan ketentuan $100=$ NOR, $010=$ MYO dan $001=$ MYO

Untuk memperoleh nilai - nilai parameter JST yang optimal sejauh ini belum ada patokan yang pasti sehingga untuk mendapatkannya para peneliti biasanya menggunakan cara eksperimen. Pada penelitian ini ditetapkan parameter MSE 0,001 dan epoch maksumum sebanyak 1000 kali. Artinya JST harus menghasilkan selisih antara output dan target 0,001 selama pelatihan sebanyak maksimum 1000 epoch seluruh pasangan data yang diujikan. Untuk mencapai goal parameter tersebut, parameter momentum dan learning rate harus dicari nilai yang terbaik dengan cara mengubah ubah nilai learning rate dari 0,1 sampai 0,9 pada momentum tetap 0,5 dan mengubah -

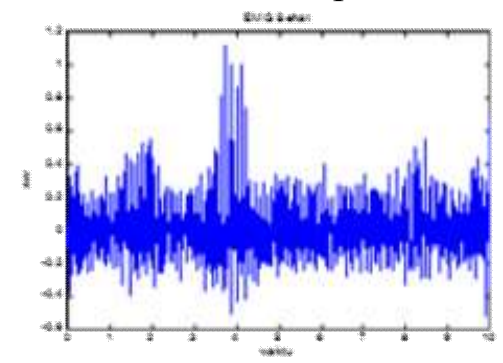

a

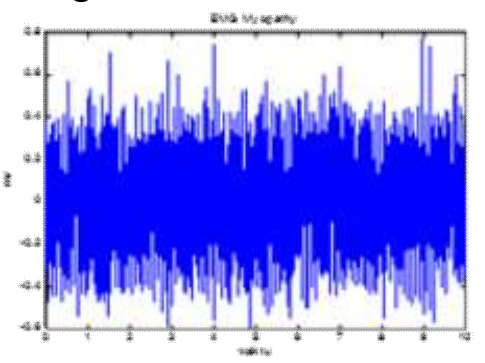

b

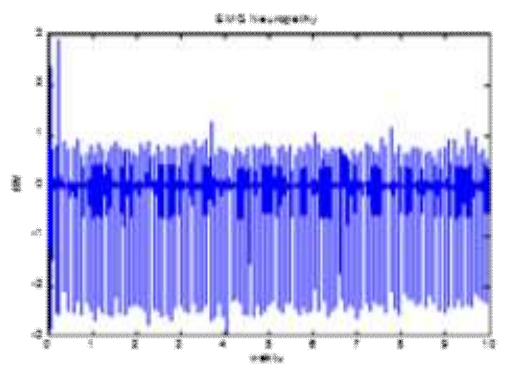

$\mathrm{C}$

Gambar 11. Contoh sinyal EMG, a) Sinyal EMG NOR,b) Sinyal EMG MYO dan c) Sinyal EMG NEU

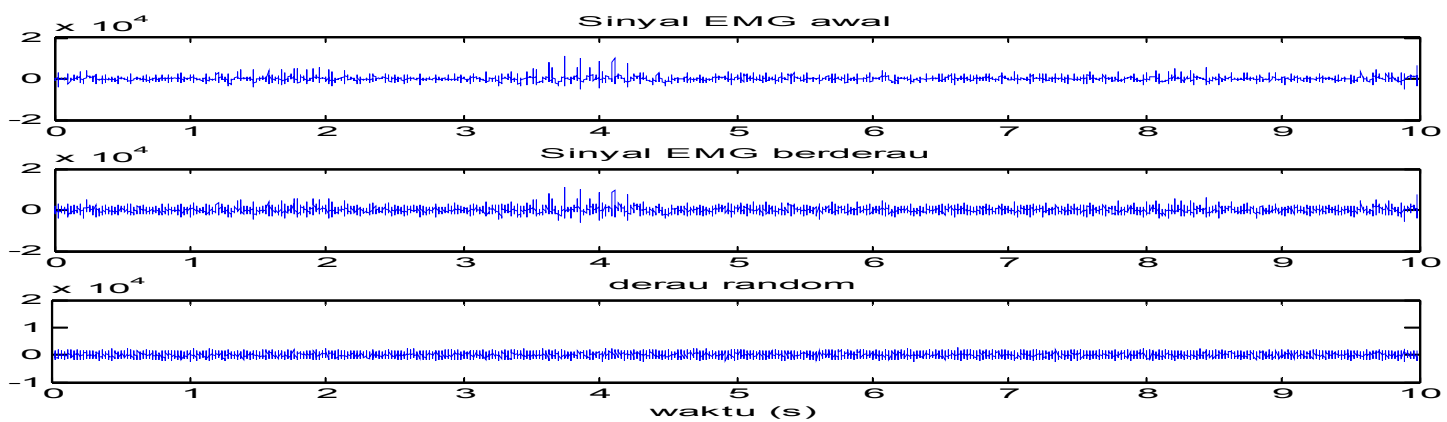

Gambar 12. Sinyal EMG NOR yang Di tambahkan Derau Sebesar 1 dB. 
Derau yang ditambahkan adalah derau random, sehingga dapat merubah morfologi dari sinyal EMG. Besaran derau yang ditambahkan pada masing - masing sinyal EMG adalah SNR (Signal to Noise Ratio) sebesar $0,1 \mathrm{~dB}, 0,2 \mathrm{~dB}, 0,5 \mathrm{~dB}, 1 \mathrm{~dB}, 2 \mathrm{~dB}, 5$ $\mathrm{dB}, 10 \mathrm{~dB}, 15 \mathrm{~dB}, 20 \mathrm{~dB}$ dan $25 \mathrm{~dB}$. penambahan derau $1 \mathrm{~dB}$ untuk sinyal EMG MYO pada gambar 13. Gambar 12, gambar 13 dan gambar 14 bagian paling atas adalah sinyal EMG awal yang belum diberi derau, gambar kedua adalah gambar yang telah diberi derau random.
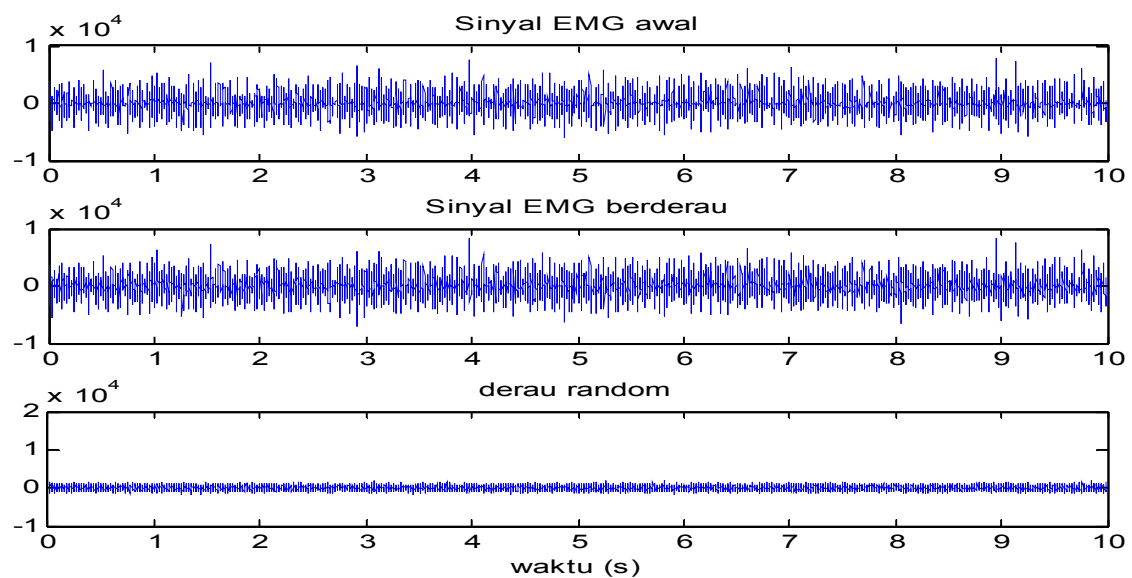

Gambar 13. Sinyal EMG MYO yang Ditambahkan Derau Sebesar $1 \mathrm{~dB}$.
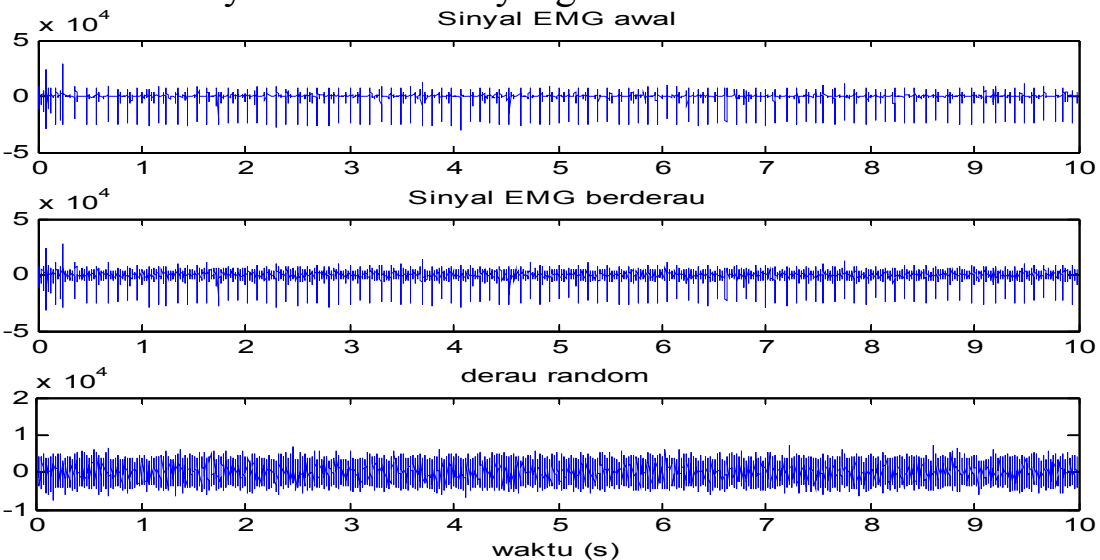

Gambar 14. Sinyal EMG NEU yang Ditambahkan Derau Sebesar $1 \mathrm{~dB}$.

\section{b. Transformasi Wavelet Sinyal EMG}

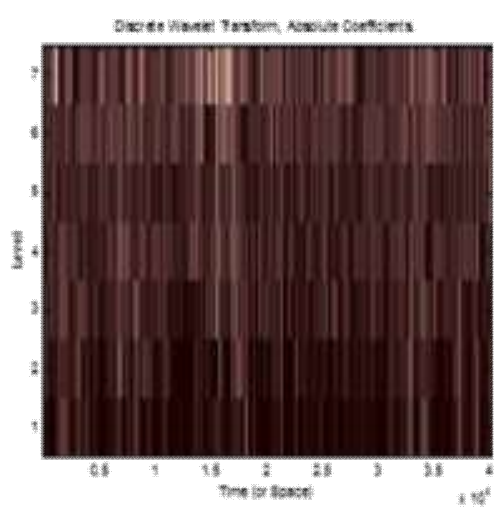

a

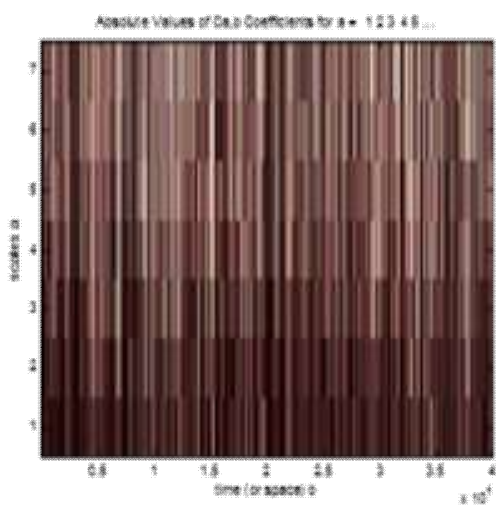

b

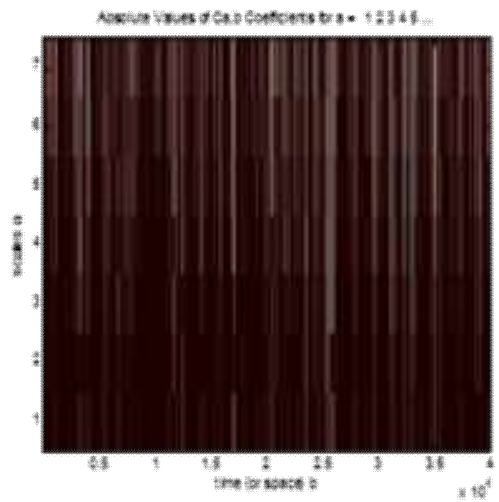

C

Gambar 15. Hasil Transformasi Wavelet Sinyal EMG a) NOR, b) MYO dan c) NEU. 


\section{c. Pemilihan Fungsi Wavelet}

Sinyal EMG memiliki karakteristik yang agak rumit, yaitu tidak stasioner (Bastiaensen Y, etc, 2008). Sehingga perlu untuk memilih fungsi wavelet yang tepat untuk mendapatkan error rekonstruksi terkecil, dengan memilih beberapa fungsi wavelet yang biasanya digunakan oleh peneliti, maka pada peneliatian ini, penulis membandingkan 2 fungsi wavelet yaitu wavelet deubechies dan wavelet symlet. Dengan melakukan dekomposisi sinyal wavelet kemudian merekonstruksi ulang, maka didapatkan error rekonstruksi dari sinyal tersebut.

Pada penelitian ini dipilih dua fungsi wavelet yang memiliki error rekonstruksi terkecil yaitu deubechies dan symlet dengan berbagai tingkat. Tingkatan tersebut yaitu $\mathrm{db} 2, \mathrm{db} 4, \mathrm{db} 5, \mathrm{db} 6$ dan db8 untuk fungsi deubechies, sym 2, sym 4, sym 5, sym 6 dan sym 8 untuk symlet. Dari hasil eksperimen ini didapatkan error terkecil menggunakan symlet 8 .

\section{d. Ekstraksi Ciri}

- Ekstraksi Ciri Data Latih

Ekstraksi ciri sinyal EMG melalui beberapa proses, yaitu dekomposisi sinyal EMG sampai 7 tingkat dengan menggunakan wavelet symlet 8 . Berdasarkan seluruh ekstraksi ciri sinyal EMG diperoleh bahwa tiap jenis EMG terdapat 8 pola ciri. Masing masing pola diperoleh dari rerata ekstraksi ciri individual yang mempunyai kemiripan kemudian dinormalisasi.

\section{- Ekstraksi Ciri Data Uji}

Ekstraksi ciri sinyal EMG Berderau juga melalui proses yang sama dengan ekstraksi ciri sinyal EMG untuk data latih, yaitu dekomposisi sinyal EMG sampai 7 tingkat dengan menggunakan wavelet Symlet 8 . Dengan frekuensi sampling $4000 \mathrm{~Hz}$. Hasil dekomposisi wavelet 7 tingkat untuk sinyal EMG. Nilai - nilai energi dekomposisi yang telah dinormalisasi menggunakan persamaan 4.5 akan menjadi input JST yang akan diuji.

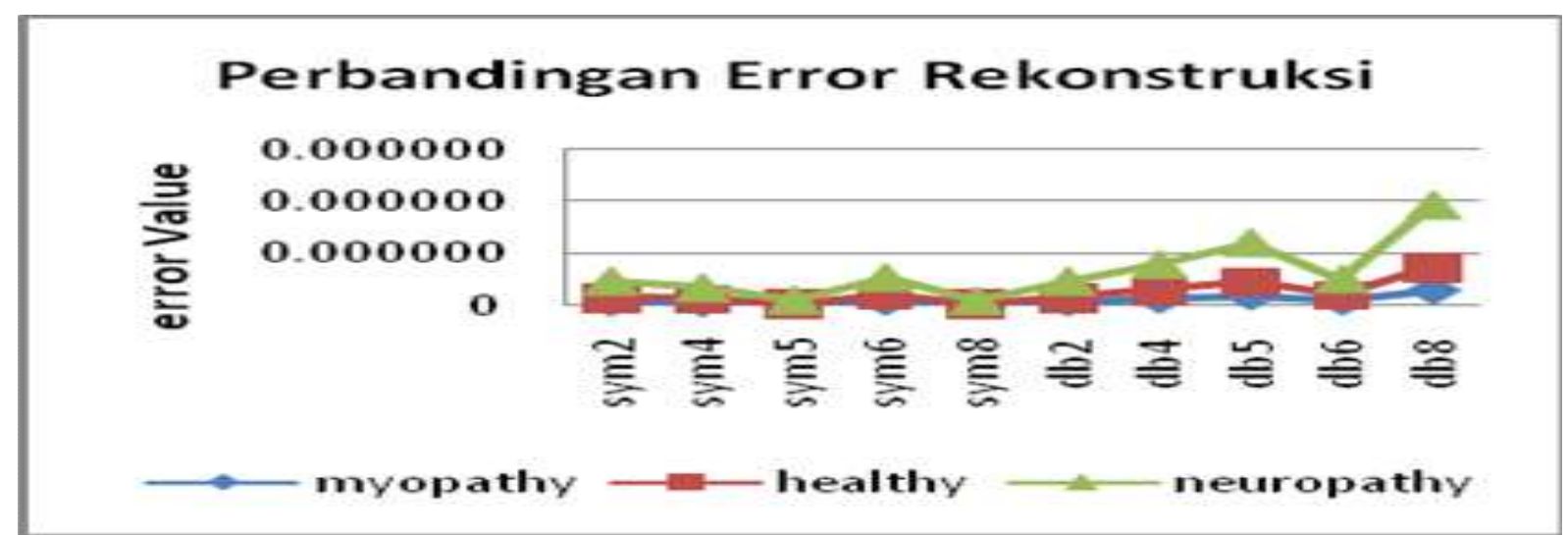

Gambar 16. Pebandingan Error Rekonstruksi Sinyal EMG.

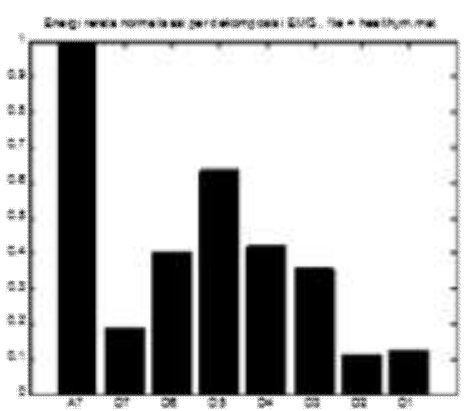

a

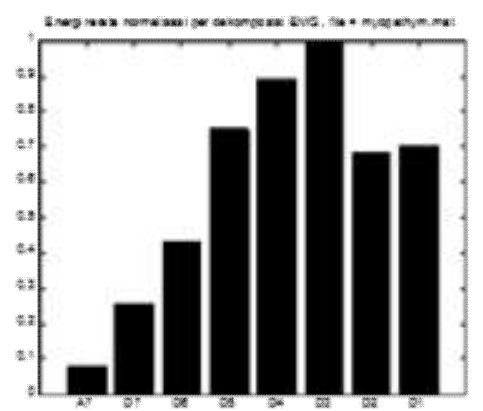

b

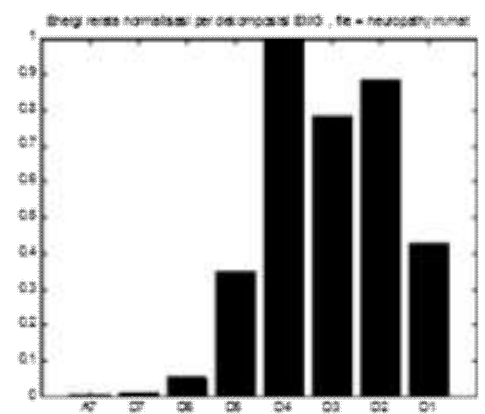

C

Gambar 17. Grafik Ekstraksi Ciri Sinyal EMG a) NOR, b) MYO, dan c) NEU. 
Tabel 3. Ekstraksi Ciri untuk Data Latih JST

\begin{tabular}{c|c|c|c}
\hline $\begin{array}{c}\text { No } \\
\text { Jenis EMG }\end{array}$ & $\begin{array}{c}\mathbf{2} \\
\text { Sehat }\end{array}$ & $\begin{array}{c}\mathbf{2} \\
\text { Myopathy }\end{array}$ & $\begin{array}{c}\mathbf{3} \\
\text { Neuropathy }\end{array}$ \\
\hline D1 & 1,000 & 0,0800 & 0,0069 \\
D2 & 0,1881 & 0,2544 & 0,0094 \\
D3 & 0,4057 & 0,4307 & 0,0530 \\
D4 & 0,6344 & 0,7514 & 0,3457 \\
D5 & 0,4207 & 0,8913 & 1,000 \\
D6 & 0,3540 & 1,000 & 0,7833 \\
D7 & 0,1134 & 0,6862 & 0,8844 \\
A7 & 0,1253 & 0,7036 & 0,4297 \\
\hline
\end{tabular}

Tabel 4. Hasil Klasifikasi JST untuk Sinyal EMG Sehat

\begin{tabular}{|c|c|c|c|c|}
\hline \multirow[t]{2}{*}{ No } & \multirow[t]{2}{*}{ Sinyal EMG Sehat } & \multicolumn{3}{|c|}{$\begin{array}{c}\text { Keberhasilan Mengenali Pola Dalam } 10 \\
\text { kali Percobaan }\end{array}$} \\
\hline & & 5 layer & 6 layer & 7 layer \\
\hline 1 & Sehat $0.1 \mathrm{bB}$ & 5 & 3 & 5 \\
\hline 2. & Sehat $0.2 \mathrm{bB}$ & 5 & 5 & 3 \\
\hline 3 & Sehat $0.5 \mathrm{bB}$ & 5 & 5 & 0 \\
\hline 4 & Sehat 1bB & 3 & 4 & 4 \\
\hline 5 & Sehat $2 b B$ & 7 & 4 & 8 \\
\hline 6 & Sehat $5 b B$ & 9 & 10 & 10 \\
\hline 7 & Sehat 10bB & 10 & 10 & 10 \\
\hline 8 & Sehat $15 b B$ & 10 & 10 & 10 \\
\hline 9 & Sehat 20bB & 10 & 10 & 10 \\
\hline \multirow[t]{2}{*}{10} & Sehat $25 \mathrm{bB}$ & 10 & 10 & 10 \\
\hline & Jumlah & 74 & 71 & 70 \\
\hline
\end{tabular}

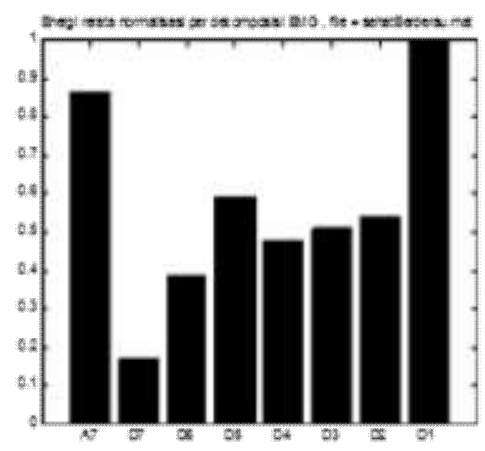

a



b

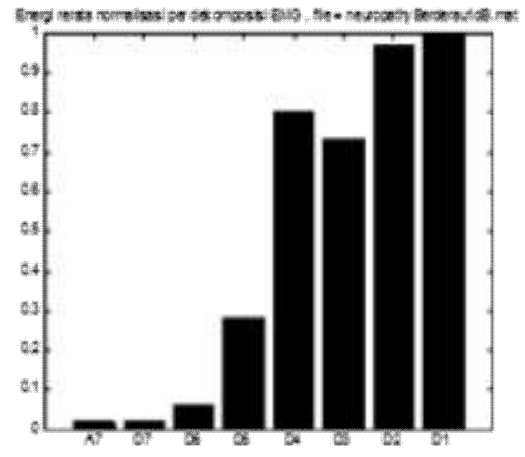

C

Gambar 18. Energi Dekomposisi Sinyal yang Diberi Derau $1 \mathrm{~dB}$ dan Dinormalisasi a) NOR, b) MYO dan c) NEU.

\section{e. Hasil Klasifikasi}

Secara keseluruhan hasil klasifikasi EMG oleh JST perambatan balik berdasarkan ekstraksi ciri energi rerata dekomposisinya seperti pada tabel 3, 4 dan 5.
Setiap sinyal dicoba sebanyak 10 kali untuk mengenali pola sinyal EMG, kemudian keberhasilan dalam mengenali pola ini dimasukkan pada tabel. Jaringan dapat mengenali pola sinyal EMG yang telah diberi derau, tetapi sampai level derau tertentu jaringan sulit untuk mengenalinya. 
Tabel 5. Hasil Klasifikasi JST untuk Sinyal EMG Myopathy

\begin{tabular}{|c|c|c|c|c|}
\hline \multirow[t]{2}{*}{ No } & \multirow[t]{2}{*}{ Jenis sinyal } & \multicolumn{3}{|c|}{$\begin{array}{c}\text { Keberhasilan Mengenali Pola Dalam } 10 \\
\text { kali Percobaan }\end{array}$} \\
\hline & & 5 layer & 6 layer & 7 layer \\
\hline 1 & Myopathy $0.1 \mathrm{bB}$ & 8 & 9 & 7 \\
\hline 2. & Myopathy $0.2 \mathrm{bB}$ & 9 & 9 & 7 \\
\hline 3 & Myopathy $0.5 \mathrm{bB}$ & 10 & 10 & 9 \\
\hline 4 & Myopathy $1 \mathrm{bB}$ & 9 & 9 & 9 \\
\hline 5 & Myopathy $2 \mathrm{bB}$ & 10 & 9 & 9 \\
\hline 6 & Myopathy $5 \mathrm{bB}$ & 10 & 9 & 10 \\
\hline 7 & Myopathy $10 \mathrm{bB}$ & 10 & 9 & 10 \\
\hline 8 & Myopathy $15 \mathrm{bB}$ & 10 & 10 & 10 \\
\hline 9 & Myopathy 20bB & 10 & 10 & 10 \\
\hline \multirow[t]{2}{*}{10} & Myopathy $25 \mathrm{bB}$ & 10 & 10 & 10 \\
\hline & Jumlah & 96 & 94 & 91 \\
\hline
\end{tabular}

Tabel 6. Hasil Klasifikasi JST untuk Sinyal EMG Neuropathy

\begin{tabular}{c|c|c|c|c}
\hline \multirow{2}{*}{ No } & \multirow{2}{*}{ Jenis sinyal } & \multicolumn{3}{|c}{ Keberhasilan Mengenali pola dalam 10 } \\
& & 5 layer & 6 layer & 7 layer \\
\cline { 2 - 5 } & Neuropathy $0.1 \mathrm{bB}$ & 5 & 7 & 6 \\
\hline 1 & Neuropathy $0.2 \mathrm{bB}$ & 7 & 6 & 7 \\
2. & Neuropathy $0.5 \mathrm{bB}$ & 7 & 7 & 7 \\
3 & Neuropathy 1bB & 8 & 6 & 8 \\
4 & Neuropathy 2bB & 8 & 7 & 7 \\
5 & Neuropathy 5bB & 9 & 10 & 9 \\
6 & Neuropathy 10bB & 10 & 10 & 9 \\
7 & Neuropathy 15bB & 10 & 10 & 10 \\
8 & Neuropathy 20bB & 10 & 10 & 10 \\
9 & Neuropathy 25bB & 10 & 10 & 10 \\
10 & Jumlah & $\mathbf{8 4}$ & $\mathbf{8 3}$ & $\mathbf{8 3}$ \\
\hline \multicolumn{4}{r}{}
\end{tabular}

Pada tabel 4.3 pemberian nilai SNR dari 0,1 sampai $2 \mathrm{~dB}$ memberikan efek yang sangat besar. Jaringan tidak dapat mengenali untuk pola ini. Untuk sinyal EMG sehat, tingkat keberhasilan jaringan yang paling akurat adalah dengan menggunakan 5 hidden layer, tingkat keberhasilan mencapai $74 \%$.

Tabel 5 adalah hasil klasifikasi sinyal EMG Myopathy, dengan pemberian derau yang bervariasi, jaringan masih mampu mengenali pola dengan baik. Bahkan dengan pemberian nilai SNR dari $0,1 \mathrm{~dB}$. Tingkat keberhasilannya melebihi $90 \%$. Jaringan dengan 5 hidden layer memiliki tingkat keberhasilan paling baik dengan 94\%.
Tabel 6 adalah hasil klasifikasi sinyal EMG Neuropathy. Dengan perlakuan yang sama terhadap sinyal EMG sebelumnya. Jaringan dapat mengenali pola sinyal EMG dengan baik. Tingkat akurasinya melebihi $80 \%$ dan yang terbaik adalah jaringan dengan 5 buah hidden layer dengan 84\% dapat mengenali pola sinyal EMG. JST perambatan balik dengan arsitektur 8 input layer, 5 hidden layer dan 3 output layer adalah yang terbaik dalam mengenali pola sinyal EMG, sehingga arsitektur ini diusulkan untuk menjadi alat klasifikasi sinyal EMG. 
Tingkat keberhasilan rata - rata untuk arsitektur JST ini adalah 84\%. Presentase tertinggi mengenali sinyal EMG adalah Myopathy dengan 94\%, diikuti Neuropathy 84\% dan EMG sehat $74 \%$.

\section{KESIMPULAN DAN SARAN}

\subsection{Kesimpulan}

Berdasarkan analisis pada hasil penelitian ini, maka dapat diperoleh beberapa kesimpulan sebagai berikut :

1. Energi rerata dekomposisi sinyal EMG 7 tingkat dari transformasi wavelet (wavelet symlet 8 ) dapat digunakan sebagai ekstraksi ciri sinyal EMG Nornal, Myopathy dan Neuropathy. Sinyal EMG yang berasal dari physionet digunakan sebagai data latih, sedangkan variasi dari sinyal tersebut digunakan sebagai data uji.

2. JST Perambatan balik mampu mengenali 3 jenis sinyal EMG yaitu Normal, Myopathy dan Neuropathy. Berdasarkan fitur ekstraksi ciri energi dekomposisi sinyal EMG. Arsitektur jaringan dengan 8 input layer, 5 hidden layer dan 3 output layer terbukti paling baik dalam pengenalan sinyal EMG. Tingkat keberhasilan tertinggi adalah pada pengenalan pola sinyal EMG Myopathy mencapai 94\%, sehingga arsitektur jaringan ini diusulkan untuk mengklasifikasi sinyal EMG.

\subsection{Saran}

Pada penelitian ini hanya terbatas pada 3 jenis sinyal EMG yang dikenali, maka untuk penelitian selanjutnya, disarankan untuk menambah jumlah sinyal yang akan dikenali dan menggunakan sinyal asli yang lebih banyak.

\section{DAFTAR PUSTAKA}

Bastiaensen Y, Schaeps T, Baeyens J.P., 2008, Analyzing an sEMG signal using wavelets, Papers of the E-Lab Master Theses' 2007-2008.

Berger P. A, Nascimento F. A. O, Rocha A. F, Carvalho J. L. A., 2007, A New Wavelet - Based Algorithm for Compression of Emg Signals.

Fausset. L., 1994, Fundamental of Neural Network (Architecture, Algorithm and Aplication), Prentice Hall, New Jersey

Kale. S. N, Dudul. S. V., 2009, Intelligent Noise Removal from EMG Signal Using Focused Time-Lagged Recurrent Neural Network, Hindawi Publishing Corporation Applied Computational Intelligence and Soft Computing Volume 2009, Article ID 129761, 12 pagesdoi : 10.1155/2009/129761.

Kusumadewi. S., 2004, Membangun Jaringan Syaraf Tiruan Menggunakan Matlab dan Exel Link, Penerbit Graha Ilmu, Yogyakarta.

Lessard C. S., 2006, Signal Processing of Random Physiological Signals, Morgan \& Claypool Publisher, USA.

Mallat S., 1999, “A Wavelet Tour of Signal Processing”, London: Academic Press.

Mesin. L, Farina. D., 2004, Simulation of Surface EMG Signals Generated by Muscle Tissues With Inhomogeneity Due to Fiber Pinnation, IEEE Transactions on Biomedical Engineering, vol. 51, no. 9.

MIT - BIH Database, Available : www.physionet.org. 
Pauk j., 2008., Different Techniques for EMG Signal Processing, Vibromechanika. Journal of Vibroengineering, volume 10, issue 4, issn 1392-8716.

Phinyomark A, Limsakul C, and Phukpattaranont P., 2009, A Novel Feature Extraction for Robust EMG Pattern Recognition, Journal of Computing, Volume 1, Issue.

Phinyomark A, Limsakul C, and Phukpattaranont P., 2011, Application of Wavelet Analysis in EMG Feature Extraction for Pattern Classification, Measurement Science Review, Volume 11, no. 2.

Puspitaningrum. D., 2006, Pengantar Jaringan Saraf Tiruan, Penerbit Andi, Yogyakarta.

Rokhana R, Kemalasari, Wardana P.S., 2009, Identifikasi Sinyal Electromyograph (EMG) Pada Gerak Ekstensi - Fleksi Siku Dengan Metode Konvolusi dan Jaringan Syaraf Tiruan, Kampus PENS ITS Sukolilo, Surabaya.

Shibata. K, Ikeda Y., 2009, Effect of Number of Hidden Neurons on Learning in Large Scale Layere Neural Network, Proceeding of ICROS SICE International Joint Convference. Fukuoka International Congress Center, Japan.

Subasi A, Yilmaz M, Ozcalik H.R., 2006, Classification of EMG Signals Using Wavelet Neural Network, Journal of Neuroscience Methode 156 (2006) 360-367.

Suhaimi, 2003, Disfungsi Autonomik dan Neuropati Perifer Pada PenderitaSirosis Hati, Digital Librari USU. 